\title{
水稳牛稔性一種の遺傳
}

（日本遺傳學會第二回大會菁演要旨）

\section{宮澤 文吾}

[管峆高等農林學校]

1914 年に關取 $\times$ 愛國の $F_{3}$ の一系統中に不稳性にして然か子粐の大 型を爲して居る一株を發見し此株から僅か数粒の結䐝しれものを得て翌年 に時れ所が二株が得られれ，その一株は常型で一株は植物體の總ての部分 が細形で牛棇性を帶びて居れ。

今茲に報告しゃらとするのは此牛稔性の子孫に就ての調査の結果であ る、之を略述すると牛稔型からは常に牛秢型と常型とを分舒して固定する 系統はるく常型は必ず常に固定する。

光づ牛稔型の不稔の程度を見ると 1918 年以後每年の調查の牛秢型 246 株常型 148 株の仨均では前者の $40.8 \%$ に對し後者は $12.0 \%$ である、 常型の $12 \%$ は何等か外界の影響に依る結果で遺傳的の原因に依るのでは ないと考へられる、所が牛秎型の方には遺傳的に此性質を持て居るものと 思はれる、併し $40.8 \%$ の小には常型の $12 \%$ に相常する不稳を混じて居 るものとすべきで $12 \%$ を根據にして計算すると筫際に不稔となるべき步 合は $32.7 \%$ となる。

1915 年以後各年の分離系統の調査の結果を合計して示すと次の粶で ある。

$\begin{array}{cccc}\text { 常型 } & \text { 卅稔型 } & \text { 計 } & \text { 牛稔型步合 } \\ 13810 & 5328 & 19188 & 27.84\end{array}$

寺尾博上は暴に牛秢型より牛秢型と常型とを $50 \%$ づつ發生する場 合を報占され近藤博士は分離に一定の此なき場合を報告されて居る、著者 る亦寺尾博士の場合と同樣次現象に相遇して居る、但し此場合の牛稔型は 
常型と何等異る所はない。五ヶ年間の調查の結果は一つの場合は牛稔型 $52.9 \%$ であb他の場合は $52.7 \%$ であつね。何れる $50 \%$ る稍多くなつ

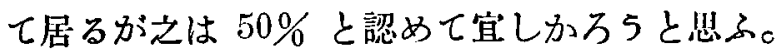

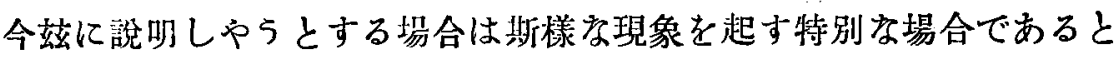
考人られる、即ち立に $\mathrm{A} ， \mathrm{~B}$ の二つの factor があるとして B は雄性配 偶子の總てを殺する雌性配偶子では B を含で居る一部は生さて居るるの と考人られる、而して幾何が生さて居るか子考へて見るに前に迅べれ常型 の $12 \%$ を基礎にして非稔型で外界の影響に依て死だ步合を出すてとが出 來る、郎ち牛稔型の雌性配偶子の牛數郎ちA を含で居るものは正常であ るが其 12\% は外界の影響に依て死ね8のとすれば生存する8のは $44 \%$ となる、そして怢型の結筫步合は $67.3 \%$ であるが此中ては上述の $44 \%$ が含せれて居るから之を引くと $23.3 \%$ が得られ此數は牛稔型を生ずべ文 $\mathrm{B}$ を含で居る配偶子の賽際に生存して居る8のに當る、然るに此數は理論 的に生存すべき數より常型に於ける 12\%に相當する數を失ふたものに當 るべさである、そして此數郎ち外界の影響に依て死だ步合は 3.2 となる、 故に生存すべさ理論數は $26.5 \%$ となるべさである。

斯樣に考へて見ると配偶子の含し factor と兩配偶子加生さて居る割 合は次に示す樣になる。

\begin{tabular}{|c|c|c|}
\hline & $\mathrm{Ab}$ & $\mathrm{aB}$ \\
\hline 송 & 50 & 0 \\
\hline 우 & 50 & 26.5 \\
\hline
\end{tabular}

斯かる制合に配偶子の數が出桃て唇れば之が自殖をすると $\frac{A b}{A b}$ は $50 \frac{\mathrm{Ab}}{\mathrm{aB}}$ は 26.5 づ\出來る筈である、そてで此割合で $\frac{\mathrm{Ab}}{\mathrm{Ab}}$ 及び $\frac{\mathrm{Ab}}{\mathrm{aB}}$ を含だ接合子が出桃るものとして計算しても或は此制合の $12 \%$ が死だも のとして之を引き去つた後汇兩者の步合出しても何れの場合る之れは 65.4:34.6 と友す。此\% と放際に得られれ 72.2: 27.8 との間には約 $7 \%$ の距嶊があつて貿際と推論との間に相當の距離がある。 
けれどる佾茲に攻究しなりればなら點がある、師ち形成されれ配偶 子は凡て必ず正常に發育するすのであるか或は含で居る factor の如何に 依て弱芽乃至は植物體の發育中に受ける故障に違がないかといるてとであ る、發芽步合を水選しれ種子で室內で調べて見れら平均 $2 \%$ の差があり 單に肉眼鑑定だけで選搑種子を苗代で移植前に調べれ結果では本均約 $8 \%$ の装があつれ、それ故卅稳型の種子は不發芽で終る割合が常型よりは少し 多几し發芽しても十分に發育し得られない苗が多いと考へられる、若し移 植當時迄に $8 \%$ が常型よりる多く失はれるとすればそして此制合は $\frac{\mathrm{Ab}}{\mathrm{a} \mathrm{B}}$ なる factor を有する接合子の死だものとすれば 34.6-8.0=26.6 となって 實驗數の 27.84 より稍少的が略隹一致するてとになる。

調查成績の總本均から考察しそ結果は以上の㥞であるが然らば分離系 統の各が良く整一に分離をして分離比偏差の變哄狀態は正常なるのである かど5かを確める必要がある、今 $\mathrm{Ab}$ 及び $\mathrm{aB}$ 孙る factor を有する配偶 子が $75: 25,74: 26,73: 27$ といふ割合に出來るるのとして計算して見る と P は夫々 $0.0037,0.373,0.368$ と将り $26 \%$ の埸合と $27 \%$ の場合と 大差はな的が $26 \%$ の場合が良く適合して居るものと見做される、從て邀 合度は高くは次いが形成せられる $\frac{\mathrm{Ab}}{\mathrm{a} \mathrm{B}}$ なる factor を有する雌性配偶子 は $26 \%$ 附近に在るるのと考へられ前に得られれ理諭数の $26.5 に$ 殆ど一 致して居るるのと見做される。 